\title{
Analysis of essential trace elements in some traditional Indian medicinal plants using instrumental neutron activation analysis and atomic absorption spectroscopy techniques
}

\author{
Department of Chemistry, \\ University of Mumbai, \\ Vidyanagari, Santacruz, Mumbai 400098, India \\ E-mail: rama.lokhande@yahoo.com \\ E-mail:mahadeoa@gmail.com \\ Pravin U. Singare* \\ Department of Chemistry, \\ Bhavan's College, \\ Munshi Nagar, Andheri, Mumbai 400058, India \\ E-mail: pravinsingare@vsnl.net \\ *Corresponding author
}

Ram S. Lokhande and Mahadeo L. Andhale

\begin{abstract}
Specific parts (fruits and leaves) of different medicinal plants often used in Indian Ayurvedic system were analysed for 18 elements (K, Mn, Na, $\mathrm{Fe}, \mathrm{Zn}, \mathrm{Cu}, \mathrm{Co}, \mathrm{Br}, \mathrm{Sm}, \mathrm{Cl}, \mathrm{La}, \mathrm{Al}, \mathrm{Cr}, \mathrm{Ca} \mathrm{Cd}, \mathrm{Ni}, \mathrm{Pb}$ and $\mathrm{Hg}$ ) by employing instrumental neutron activation analysis (INAA) and atomic absorption spectroscopy (AAS) techniques. The samples were irradiated with thermal neutrons in a nuclear reactor and the induced activities were counted by $\gamma$-ray spectrometry using efficiency calibrated high resolution high purity germanium (HPGe) detector. Most of the medicinal plants were found to be rich in one or more of the elements under study. The elemental concentration in different part of medicinal plants and their biological effects on human beings are discussed.
\end{abstract}

Keywords: instrumental neutron activation analysis; INAA; atomic absorption spectroscopy; AAS; medicinal plants; trace elemental analysis; inter-elemental correlations; healthcare; Ayurvedic medicine; biological effects; curative properties; India.

Reference to this paper should be made as follows: Lokhande, R.S., Andhale, M.L. and Singare, P.U. (2011) 'Analysis of essential trace elements in some traditional Indian medicinal plants using instrumental neutron activation analysis and atomic absorption spectroscopy techniques', Int. J. Immunological Studies, Vol. 1, No. 3, pp.285-296.

Biographical notes: Ram S. Lokhande received his Master's in Physical Chemistry from the Mumbai University in 1976 and PhD in Chemistry from the Advanced Study Centre in Nuclear Chemistry, University of Pune in 1981. He was working as a Professor of Chemistry and has many research papers published and presented at national and international level. His research areas of interest are radio analytical nuclear chemistry, environmental chemistry, 
solvent extraction and ion exchange techniques. He is a member of several scientific societies such as ISAS, NAARI and INS all from the BARC, Mumbai and the Indian Council of Chemists, Agra, India.

Mahadeo L. Andhale received his Master's and MPhil from the University of Pune. He received his $\mathrm{PhD}$ from the University of Mumbai in 2007. He has presented several research papers on application of INAA technique in various national conferences and has international research papers to his credit. Presently, he is working as an Assistant Professor in Chemistry at the Vartak College, Mumbai.

Pravin U. Singare received his Master's in Inorganic Chemistry in 1997 and $\mathrm{PhD}$ in Chemistry in 1999, both from the University of Mumbai, India. He has worked at the Sikkim Mining Corporation, Sikkim, India, on a project related to the concentration of $\mathrm{Cu} / \mathrm{Pb} / \mathrm{Zn}$ sulphide ores. He is presently an Assistant Professor in Chemistry at the Bhavan's College, Andheri, Mumbai. His research areas of interest are radio analytical nuclear chemistry, ion exchange techniques and environmental analysis. He is a member of several scientific societies such as ISAS, NAARI and INS all from the BARC, Mumbai and the Indian Council of Chemists, Agra, India.

\section{Introduction}

There are many references to the curative properties of several herbs in the ancient Indian literature, Rigveda, though a more detailed account is found in the Atharvaveda from where Ayurveda, the Indian traditional healthcare system (ayus $=$ life, veda $=$ knowledge, meaning science of life) originated. Fairly comprehensive information about herbs has been recorded in two treatises Charak Samhita and Shusruta Samhita - a base for Ayurvedic system of medicine (Parchure, 1983; Sharma, 1993). These herbs are now being increasingly used in cosmetics, food as well as alternative medicine (Bakhru, 1998). Some of the ingredients of allopathic and most of the Ayurvedic and homeopathy medicines are derived from plants. Traditional Indian medical herbs used for strengthening the body immune system are known to have many essential and nutritional elements. Their excess or deficiency may disturb normal biochemical functions of the body (Iyengar, 1989). Some western scholars have pursued the analysis of various Indian plants and herbs for their medicinal properties (Ambasta, 1986). Most studies on such medicinal plants pertain to their organic contents, viz. essential oils, glycosides, vitamins, alkaloids and other active components and their pharmacological/therapeutic effects. Besides several organic compounds, it is now well established that many trace elements play a vital role in general well-being as well as in the cure of diseases (Prasad, 1993; Underwood, 1977). Several studies have reported elemental contents in plant extracts, which are consumed by us either as an herbal health drink or medicine (Abou Arab and Donia, 2000; Kumar et al., 2005; Powel et al., 1998). These elements are present at varying concentrations in different parts of the plants, especially in roots, seeds and leaves which are used as a dietary item as well as ingredient in the Ayurvedic medicinal preparation. The leaves of the plants are still used in some countries, as for instance, in Malaysia (Majid et al., 1995), Greece (Kanias et al., 1993) and India (Patel, 1986) particularly for their therapeutic effects. Since these trace elements constitute a minute 
fraction in different parts of the medicinal plants, a sensitive and reliable analytical technique is a prerequisite for obtaining precise and accurate data.

Considering the importance of trace elements in various human metabolic processes and also considering their curative properties, in the present investigation we have applied one of the sensitive analytical techniques like instrumental neutron activation analysis (INAA) to study the essential elemental content in different parts of Indian medicinal plants and herbs. The overall impact of these essential trace elements on human health is also discussed. Due to increasing industrialisation and environmental pollution, the study was also extended to estimate the level of toxic elements present in these medicinal plant samples. Even though the direct link between the essential elemental content and their curative capacity is not yet established, the experimental data of the present work will be of immense importance in the synthesis of new Ayurvedic formulations. Also, it will help in deciding the proportion of various active constituents and managing dose of a particular formulation.

\section{Experimental}

\subsection{Sampling}

The various medicinal plants (Table 1) in the form of fruits and leaves were collected from and around the Keshav Shrushti, Bhayander and Narsing K. Dube College, Nalasopara, Maharashtra, India. Surface contaminants of the plant samples were removed by washing with deionised water twice and then with deionised double distilled water. The leaves were air dried in a clean drying chamber and then dried at $80^{\circ} \mathrm{C}$ for overnight in an oven. The samples were powdered in agate mortar and passed through 100-mesh sieve. Sampling was done from this powder. Two biological reference materials namely IAEA CRM V-10 and CTA VTL-2 (IJCT Poland) were used as a control and reference multielemental standard respectively. The concentrations of all the elements investigated in this study are well certified in the reference material.

Table 1 Medicinal plant samples selected for the study

\begin{tabular}{|c|c|c|c|}
\hline Sample number & Local name & Botanical name & Parts of plants: medicinal use \\
\hline 1 & Hirda & Terminalia chebula & Fruits: liver tonic, piles \\
\hline 2 & Tamalapatra & Cinnamomum tamala & Leaves: abortions cannery \\
\hline 3 & Aghada & Achyranthes aspera & $\begin{array}{l}\text { Leaves: liver tonic, treat excessive } \\
\text { hunger, piles, stone, wounds, } \\
\text { difficult labour, accidental } \\
\text { wounds, eye disease, ear disease, } \\
\text { head disease, dog-bite, abdominal } \\
\text { pain, jaundice, insomnia and pain } \\
\text { in vagina }\end{array}$ \\
\hline 4 & Kakadsingi & Rhus succedanea & Leaves: cough, constipation \\
\hline 5 & Kumari mala & Aloe vera & $\begin{array}{l}\text { Leaves: liver disorder, blood } \\
\text { purifier, treat spleen enlargement, } \\
\text { epilepsy, penile wart, dysuria, } \\
\text { inflammation in penis, abscess, } \\
\text { jaundice, gulma, headache and } \\
\text { amenorrhoea }\end{array}$ \\
\hline
\end{tabular}




\subsection{Irradiation and counting}

About 50 to $80 \mathrm{mg}$ of each sample was sealed in a polyethylene cover. Samples, reference standard and control sample were packed together and irradiated in the E8 position of the Apsara reactor, BARC. Irradiation time was varied between $30 \mathrm{~min}$ and $7 \mathrm{~h}$ depending on the half lives of the activation products. The sub-cadmium neutron flux in this position is in the order of $1 \times 10^{12} \mathrm{~cm}^{-2} \mathrm{~s}^{-1}$. The samples were also irradiated at Dhruva reactor for $1 \mathrm{~d}$ in order to determine the elemental concentration of the long-lived radionuclides, such as $\mathrm{Fe}$. The short irradiation and counting were conducted at the reactor site followed by spectra unfolding at the Radiochemistry Division of BARC, Mumbai. The radionuclides used for the analysis and their $\gamma$ energies are given in Table 2. All the samples and SRMs were counted at a calibrated sample-detector distance from a high purity germanium (HPGe) detector (Ortec) with $25 \%$ relative efficiency and $2.1 \mathrm{keV}$ resolution at $1,332.5 \mathrm{keV}$ of ${ }^{60} \mathrm{Co}$ line, which was connected, to an IBM PC XT computer system. Most of the short lived isotopes contributing to the dead time belong to the elements present in major $\mathrm{Ca}$ and minor $\mathrm{Al}$ levels. The presence of different elements analysed in various medicinal plants was confirmed by measuring their characteristic $\gamma$-ray energy as well as half lives which are in good agreement with the literature values. Radioactivity measuring times were chosen not to exceed 0.2 times the half lives of the radionuclide of interest. Long irradiated samples were brought to Radiochemistry Laboratory at Mumbai University and $\gamma$-activity was measured. Counting was followed for $1,2,6$ and $12 \mathrm{~h}$ at different intervals up to $3 \mathrm{~m}$. Care was taken to obtain maximum elemental information from more than one counting and the reproducibility of data was checked. Elemental concentrations of various Ayurvedic medicinal plants were calculated by relative method using control and reference multielemental standard as comparators.

Table 2 Radionuclides used for the analysis and their $\gamma$-energies

\begin{tabular}{lc}
\hline Nuclide & $\gamma$-ray energy in keV \\
\hline${ }^{42} \mathrm{~K}$ & 1,524 \\
${ }^{56} \mathrm{Mn}$ & 847 \\
${ }^{24} \mathrm{Na}$ & 1,368 \\
${ }^{59} \mathrm{Fe}$ & 1,099 \\
${ }^{65} \mathrm{Zn}$ & 1,115 \\
${ }^{64} \mathrm{Cu}$ & 1,040 \\
${ }^{60} \mathrm{Co}$ & 1,332 \\
${ }^{82} \mathrm{Br}$ & 776 \\
${ }^{153} \mathrm{Sm}$ & 103 \\
${ }^{38} \mathrm{Cl}$ & 1,642 \\
${ }^{140} \mathrm{La}$ & 1,596 \\
${ }^{28} \mathrm{Al}$ & 1,779 \\
\hline
\end{tabular}

Note: Thermal neutron flux: $10^{12}-10^{13} \mathrm{n} \mathrm{cm}^{-2} \mathrm{~s}^{-1}$

\subsection{Atomic absorption spectrometer measurement}

The samples in the powdered form were accurately weighed and digested in (5:1) mixture of nitric acid and perchloric acid (Herber and Stoeppler, 1994). After digestion few drops of concentrated $\mathrm{HCl}$ was added. The solution was heated gently and then filtered. The 
residue was again subjected to digestion and filtrate was collected. The entire filtrate was diluted suitably with distilled deionised water. The dilute filtrate solution was used for analysis of elements of interest $(\mathrm{Cr}, \mathrm{Ca}, \mathrm{Cd}, \mathrm{Ni}, \mathrm{Pb}$ and $\mathrm{Hg}$ ) by atomic absorption spectroscopy (AAS) (Perkin Elmer 3100 model) using suitable hollow cathode lamps. The concentration of various elements was determined by relative method using A.R. grade solutions of elements of interest. The standard conditions for atomic absorption measurement are represented in Table 3.

Table 3 Standard conditions for atomic absorption measurement

\begin{tabular}{lcccc}
\hline Element & Wavelength $(\mathrm{nm})$ & Slit width $(\mathrm{nm})$ & Sensitivity check $(\mathrm{ppm})$ & $\begin{array}{c}\text { Lamp current } \\
(\mathrm{mA})\end{array}$ \\
\hline $\mathrm{Cr}$ & 357.9 & 0.2 & 4.0 & 7 \\
$\mathrm{Ca}$ & 422.9 & 0.5 & 4.0 & 10 \\
$\mathrm{Cd}$ & 228.8 & 0.5 & 1.5 & 4 \\
$\mathrm{Ni}$ & 232.0 & 0.5 & 7.0 & 4 \\
$\mathrm{~Pb}$ & 283.6 & 0.5 & 20.0 & 5 \\
$\mathrm{Hg}$ & 253.7 & 0.5 & 200.0 & 4 \\
\hline
\end{tabular}

\section{Results and discussion}

The SRMs of biological origin were analysed for quality control and method validation. It was observed that most elemental contents are within $\pm 10 \%$ of the certified values. Standard deviations were also relatively small. The values listed in the Table 4 (which are averages of three independent measurements) are having the precision of $\sim \pm 2$ to $10 \%$.

An examination of the data from Table 4 shows that different medicinal plants contain elements like $\mathrm{K}, \mathrm{Mn}, \mathrm{Na}, \mathrm{Fe}, \mathrm{Zn}, \mathrm{Cu}, \mathrm{Co}, \mathrm{Br}, \mathrm{Sm}, \mathrm{Cl}, \mathrm{La}, \mathrm{Al}, \mathrm{Cr}, \mathrm{Ca}, \mathrm{Cd}, \mathrm{Ni}, \mathrm{Pb}$ and $\mathrm{Hg}$ in various proportions. The presence of these elements in different plants was confirmed by measuring the half life of the corresponding radioisotope formed as well as their $\gamma$-energies. The elements $\mathrm{Cr}, \mathrm{Ca}, \mathrm{Cd}, \mathrm{Ni}, \mathrm{Pb}$ and $\mathrm{Hg}$ were analysed by AAS technique by measuring the absorbance of the species at its resonance wavelength. The variation in elemental concentration is mainly attributed to the differences in botanical structure, as well as in the mineral composition of the soil in which the plants are cultivated. Other factors responsible for the variation in elemental content are preferential absorbability of the plant, use of fertilisers, and irrigation water (Rajurkar, and Pardeshi, 1997). The active constituents of the medicinal plants are the metabolic products of the plant cells. A number of trace elements play an important role in the metabolism. These elements are called essential. An element is considered essential for a plant if the plant fails to grow normally and complete its life cycle in a medium adequately removed from the element whereas in the presence of the suitable chosen concentration of that element it grows and reproduces normally. An examination of the data from Table 4 shows that leaves of Aghada are rich in $\mathrm{K}$ and $\mathrm{Na}(15.62$ and $10.10 \mathrm{mg} / \mathrm{g})$ respectively, while the leaves of Kumarimala show minimum $\mathrm{K}$ and $\mathrm{Na}$ content $(6.66$ and $0.34 \mathrm{mg} / \mathrm{g})$ respectively. The regulation of potassium is intimately involved with that of sodium and the two are largely interdependent. Potassium is accumulated within human cells by the action of the $\mathrm{Na}^{+}, \mathrm{K}^{+}$- ATPase (sodium pump) and it is an activator of some enzymes; in particular co-enzyme for normal growth and muscle function [Birch and Padgham, 
(1994), p.531]. The calcium content in various medicinal plants analysed varies from $1.32 \mathrm{mg} / \mathrm{g}$ in Kumarimala to $11.50 \mathrm{mg} / \mathrm{g}$ in Hirda. Calcium is essential for healthy bones, teeth and blood (Charles, 1992; Hughes, 1972). The health of the muscles and nerves depends on calcium. It is required for the absorption of dietary vitamin $\mathrm{B}$, for the synthesis of the neurotransmitter acetylcholine, for the activation of enzymes such as the pancreatic lypase. The recommended daily allowance for $\mathrm{Ca}$ for children is between 500 and 1,000 $\mathrm{mg}$ and $800 \mathrm{mg}$ for adults. The higher Ca content in fruits of Hirda suggests its possible use to overcome deficiency of $\mathrm{Ca}$. The elements like $\mathrm{Zn}, \mathrm{Fe}$ and $\mathrm{Cr}$ are essential trace elements (micro nutrients) for living organisms. Zinc is relatively non-toxic [Prasad, (1982), p.3]. Zinc deficiency is characterised by recurrent infections, lack of immunity and poor growth. Growth retardation, male hypogonadism, skin changes, poor appetite and mental lethargy are some of the manifestations of chronically zinc-deficient human subjects [Prasad, (1982), p.3]. Zinc is necessary for the growth and multiplication of cells (enzymes responsible for DNA and RNA synthesis), for skin integrity, bone metabolism and functioning of taste and eyesight [Thunus and Lejeune, (1994), p.333, 667]. From the results obtained, it is observed that the $\mathrm{Zn}$ content is minimum in Aghada $(10.40 \mu \mathrm{g} / \mathrm{g})$ and maximum in Hirda $(54.40 \mu \mathrm{g} / \mathrm{g})$. The higher concentration of zinc in fruits of Hirda, suggests its possible use in treatment of worms and skin disease. Iron occupies a unique role in the metabolic process. The role of iron in the body is clearly associated with hemoglobin and the transfer of oxygen from lungs to the tissue cells [Sigel, (1978), p.417]. Iron deficiency is the most prevalent nutritional deficiency in humans [Reddy et al., (1987), p.429] and is commonly caused by insufficient dietary intake, excessive menstrual flow or multiple births. In this case, it results especially anaemia. In various medicinal plants samples analysed, the $\mathrm{Fe}$ content was observed maximum in Tamalapatra $(941 \mu \mathrm{g} / \mathrm{g})$ and Kakadsingi $(917 \mu \mathrm{g} / \mathrm{g})$ while Hirda shows minimum Fe content of $158 \mu \mathrm{g} / \mathrm{g}$. Hence the leaves of Tamalapatra and Kakadsingi may also be advised to compensate for an iron deficiency. Chromium plays an important role in diabetes treatment. It is an important element required for the maintenance of normal glucose metabolism. The function of chromium is directly related to the function of insulin, which plays a very important role in diabetes. Chromium is found in the pancreas, which produces insulin. One usable form of chromium is the glucose tolerance factor (GTF) (Zetic et al., 2001), an inorganic compound containing glutamic acid, cysteine and niacin. The absorption of the trivalent chromium in GTF is about $10 \%$ to $25 \%$. It enhances the removal of glucose from the blood. The important constituent of GTF is Cr which helps in the potentiating of insulin (Anderson, 1989).Chromium also acts as an activator of several enzymes. Deficiency of chromium decreases the efficiency of insulin and increases sugar and cholesterol in the blood. Chromium deficiency can cause an insulin resistance, impair in glucose tolerance and may be a risk factor in artherosclerotic disease [Mertz, (1982), p.315]. From the results obtained, it is observed that $\mathrm{Cr}$ content is high in Hirda $(11.30 \mu \mathrm{g} / \mathrm{g})$. Hence the use of this medicinal plant may also be recommended for the treatment and control of diabetics. In experiments conducted by Anke et al. (1988) with growing, gravid and lactating goats, a poor Br-nutrition $(<1 \mathrm{mg} / \mathrm{g}$ dry matter) led to a significantly reduced growth, a worse conception rate, reduced milk fat production and decreased hemoglobin content. From our results it appears that the $\mathrm{Br}$ content was observed to be high $(62.50 \mu \mathrm{g} / \mathrm{g})$ in Hirda which suggests its possible use in preparation of the drugs for curing natural diuretic, phlegm eliminating and stomach invigorating diseases (Chen et al., 1993) and purifying breast milk. However, further investigations regarding possible essentiality of $\mathrm{Br}$ are 
necessary due to the fact that $\mathrm{Br}$ accumulates well in plants due to the application of agricultural chemicals such as methyl bromide as fumigant. The higher Mn content was observed in plant samples like Hirda $(134.0 \mu \mathrm{g} / \mathrm{g})$ and Aghada $(77.80 \mu \mathrm{g} / \mathrm{g})$. It is important here to note that $\mathrm{Mn}$ is an essential element required for various biochemical processes (Guenther and Konieczynski, 2003). Mn is important for several enzymatic processes. It helps in eliminating fatigue and reduces nervous irritability (Hamilton et al., 1994; O'Dell and Sunde, 1997; Prasad, 1993; Shils and Young, 1988). Hence use of the medicinal plants like Hirda and Aghada may help to supplement Mn for various body functions. The Co content was observed to be high in plant samples like Hirda $(4.30 \mu \mathrm{g} / \mathrm{g})$. Cobalt is an essential element for the plants having the capability to fix nitrogen in the root tubercles. Animals are able to synthesise vitamin B12, which is the main source of $\mathrm{Co}$ in animal foods. Nevertheless, only a part of Co in food derived from animals is present in the form of cobalamines. The recommended daily intake of vitamin B12 for adults is $3 \mathrm{mg}(0.13 \mathrm{mg} \mathrm{Co})$, taking into account that only $50 \%$ is absorbed in the intestine [Thunus and Lejeune, (1994), p.333, 667]. In humans, deficiency of vitamin B12 leads to a megaloblastic anemia. Cobalt also plays an important role in thyroid metabolism in humans. The elements like $\mathrm{Hg}, \mathrm{Pd}, \mathrm{Cd}$ and $\mathrm{Ni}$ are supposed to be toxic in nature and their presence in trace amount in various medicinal plant sample analysed is due to the pollution arising from automobile and industrial activities.

\subsection{Inter-elemental correlations}

Several literature reports suggest interrelationship of essential elements like $\mathrm{K}, \mathrm{Na}, \mathrm{Fe}$ and Zn (Herber and Stoeppler, 1994; Kumar et al., 2005; Underwood, 1977). The regulation of metal ion flows, especially of $\mathrm{K}^{+}$and $\mathrm{Na}^{+}$, is crucial to life and is most clearly exemplified by the ionic movements that occur in nerve cells during excitation and transmission of the action potential. The regulation of potassium is intimately involved with that of sodium and the two are largely interdependent. From the experimental data, it is observed that $\mathrm{K} / \mathrm{Na}$ ratio varies from minimum of 1 in Kakadsingi to maximum of 20 in Kumarimala. The result indicates that in Kakadsingi potassium content is 1 times of sodium, while in Kumarimala it is 20 times. The variation of $\mathrm{K} / \mathrm{Na}$ ratio for different plant samples is graphically represented in Figure 1. The two transition elements $\mathrm{Fe}$ and $\mathrm{Zn}$ are well known for their role in biochemical processes (Kumar et al., 2005). Iron deficiency is common in uremic patients, it causes substantial blood losses. Some reports indicate that dysgeusia, poor food intake, and impaired sexual function, which are common problems of uremic patients, may be improved by zinc supplements (Shils and Young, 1988). In blood, about $85 \%$ of the zinc combines with protein for transport after its absorption, and its turnover is rapid in the pancreas. Deficiency of zinc causes diabetic hyposima, hypogeusia or coma (Rajurkar and Pardeshi, 1997). The availability of $\mathrm{Zn}$ in the range of 14.8-28.4 $\mu \mathrm{g} / \mathrm{g}$ may be beneficial for diabetic patients as its deficiency has been correlated with acute and chronic mal absorption states (Garg et al., 2005; O’Dell and Sunde, 1997). From the results of different medicinal plants analysed, $\mathrm{Fe} / \mathrm{Zn}$ ratio varies from 3 in Hirda to 48 in Tamalapatra (Figure 2).In general, it may be mentioned that interrelationship of several elements in medicinal herbs suggest synergistic or antagonistic effects, thus providing various elements to the body in bioavailable form in a balanced manner with almost no harmful effects except some environmental contaminants. These, however, should be avoided by collecting herbs grown in a clean and well controlled environment (Kumar et al., 2005). 
Table 4 Elemental analysis of some medicinal plants by NAA and AAS techniques

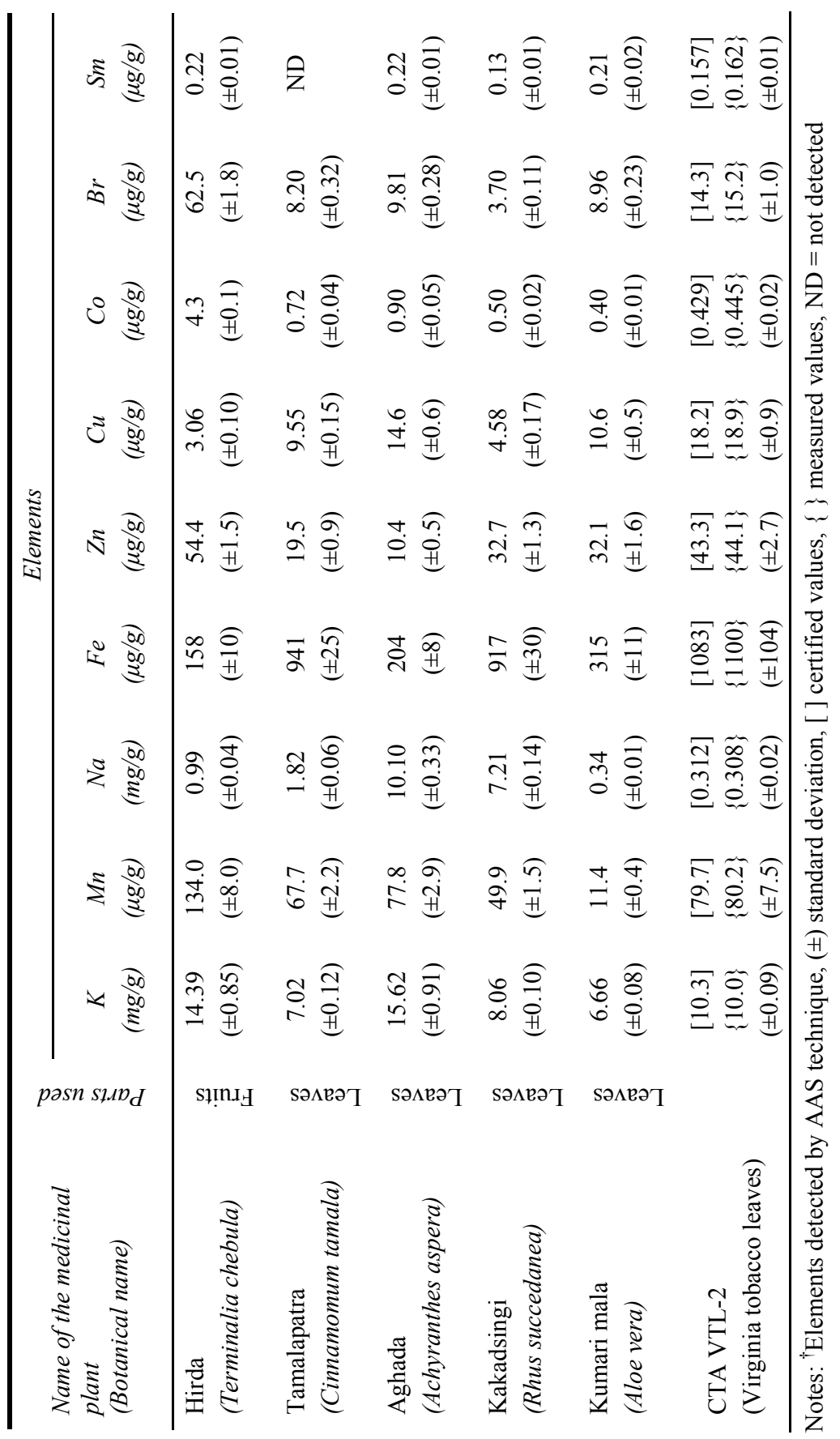


Table 4 Elemental analysis of some medicinal plants by NAA and AAS techniques (continued)

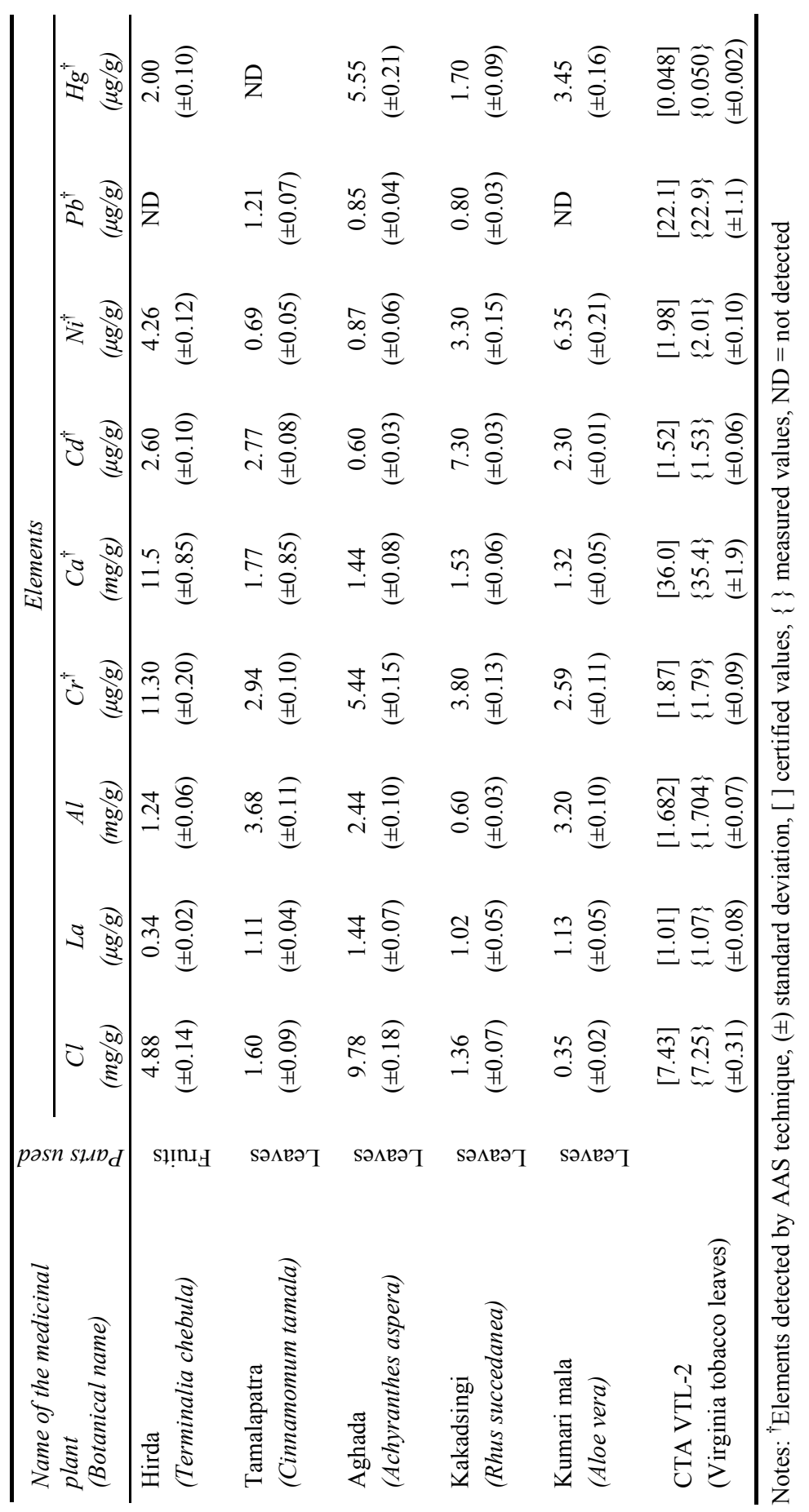


Figure 1 Variation of $\mathrm{K} / \mathrm{Na}$ ratio in different medicinal plant samples

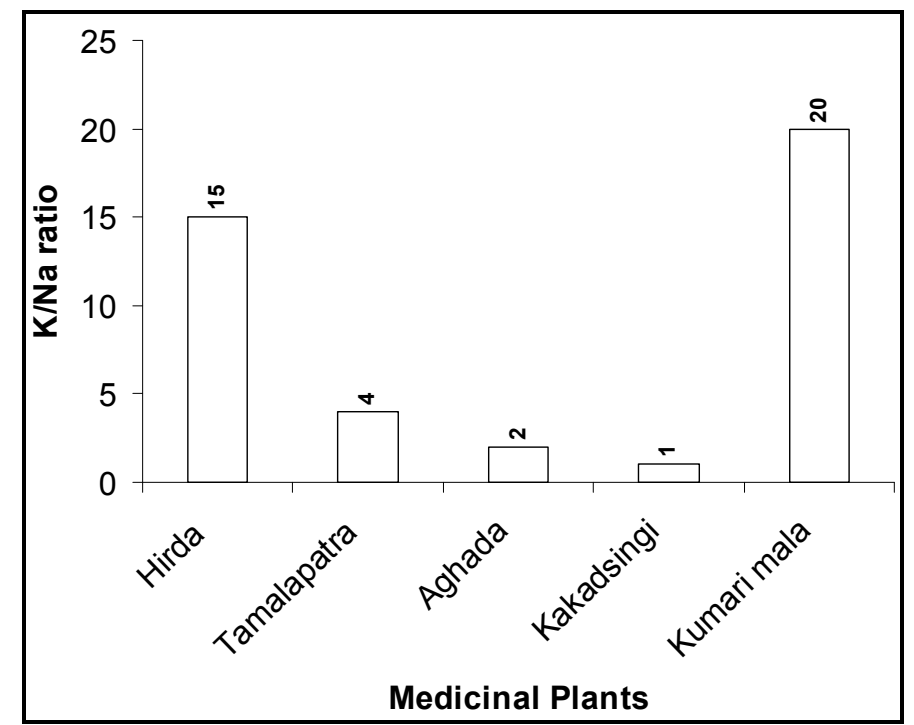

Figure 2 Variation of $\mathrm{Fe} / \mathrm{Zn}$ ratio in different medicinal plant samples

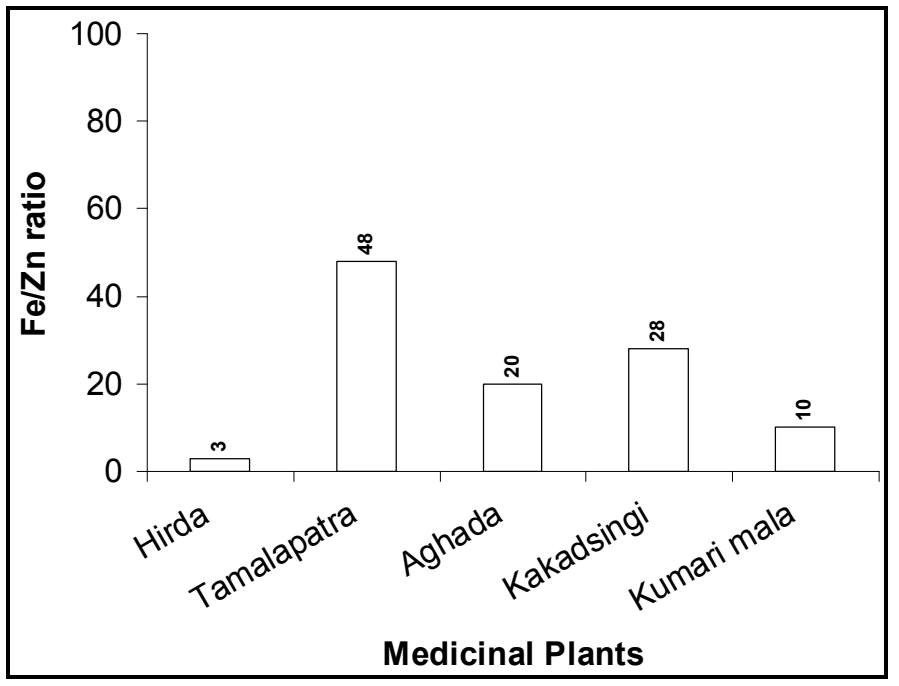

\section{Conclusions}

Although there appears to be little knowledge of the precise molecular mechanisms, many Ayurvedic preparations nevertheless appear to demonstrate significant success in treatment of complex diseases. Presumably Ayurvedic medicines contain trace elements in a bioavailable form and their impact on the overall pharmacological action cannot be ruled out. Although the direct link between elemental content and curative capability is yet to be established, such studies are vital to understanding the pharmacological action 
of herbs. The data obtained in the present work will be helpful in the synthesis of new Ayurvedic drugs which can be used for the control and cure of various diseases. In order to develop a stronger basis for appreciating the curative effects of medicinal plants, there is a need to investigate, their elemental composition. It has been demonstrated that INAA, with multi-elemental characterisation over a wide range of concentration, its blank free-nature and minimum sample preparation is ideal for such studies.

\section{Acknowledgements}

The authors are grateful to the editorial board of IJIS for their valuable suggestions; all errors remain ours.

\section{References}

Abou Arab, A.A.K. and Donia, M.A.A. (2000) 'Heavy metals in Egyptian spices and medicinal plants and the effect of processing on their levels', J. Agri. Food Chem., Vol. 48, No. 6, pp.2300-2304.

Ambasta, S.P. (1986) The Useful Plants of India, CSIR, New Delhi, India.

Anderson, R.A. (1989) 'Essentiality of chromium to humans', Sci. Total Environ., Vol. 86, Nos. 1-2, pp.75-81.

Anke, M., Groppel, B., Arnhold, W. and Larger, M. (1988) 'Essentiality of the trace element Bromine', in Briitter, P. and Schramel, P. (Eds.): Trace Element Analytical Chemistry in Medicine and Biology, Vol. 5, pp.619-629, Walter de Gruyter, Berlin, New York.

Bakhru, H.K. (1998) Herbs that Heal Natural Remedies for Good Health, Orient Paperbacks, Division of Vision Book Pvt. Ltd., New Delhi, India.

Birch, N.J. and Padgham, C. (1994) 'Potassium', in Seiler, H.G., Sigel, A. and Sigel, H. (Eds.): Handbook on Metals in Clinical and Analytical Chemistry, pp.531-535, Marcel Dekker, New York.

Charles, P. (1992) 'Calcium absorption and calcium bioavailability', J. Int. Med., Vol. 231, No. 2, pp.161-165.

Chen, K.S., Tseng, C.L. and Lin, T.H. (1993) 'Trace elements in natural drugs determined by INAA', J. Radioanal. Nucl. Chem., Vol. 170, No. 1, pp.265-280.

Garg, A.N., Kumar, A., Maheshwari, G. and Sharma, S. (2005) 'Isotope dilution analysis for the determination of zinc in blood samples of diabetic patients', J. Radioanal. Nucl. Chem., Vol. 263, No. 1, pp.39-43.

Guenther, W. and Konieczynski, P. (2003) 'Speciation of Mg, Mn and Zn in extracts of medicinal plants', Anal. Bioanal. Chem., Vol. 375, No. 8, pp.1067-1073.

Hamilton, E.M.N., Whitney, E.N. and Sizer, F.S. (1994) Nutrition: Concepts and Controversies, 4th ed., West Publishing Co., St. Paul, MN, USA.

Herber, R.F.M. and Stoeppler, M. (Eds.) (1994) Trace Element Analysis in Biological Specimens, Elsevier, New York.

Hughes, M.N. (1972) The Inorganic Chemistry of Biological Processes, Wiley, London.

Iyengar, G.V. (1989) Elemental Analysis of Biological Systems - Biomedical Environmental, Compositional and Methodological Aspects of Trace Elements, CRC Press, Florida, Boca Raton. 
Kanias, G.D., Kilikoglou, V., Tsitsa, E. and Loukis, A. (1993) 'Determination and statistical analysis of trace element and active constituent concentrations in the medicinal plant Eucalyptus Camaldulensis Dehnh (E. Rostratus schlecht)', J. Radioanal. Nucl. Chem., Vol. 169, No. 2, pp.483-491.

Kumar, A., Nair, A.G.C., Reddy, A.V.R. and Garg, A.N. (2005) 'Analysis of essential elements in Pragyapeya - a herbal drink and its constituents by neutron activation', J. Pharma. Biomed. Anal., Vol. 37, No. 4, pp.631-638.

Majid, A.A.B., Sarmani, S., Yusoe, N.I., Wie, Y.K. and Hamzah, F. (1995) 'Trace elements in Malaysian medicinal plants', J. Radioanal. Nucl. Chem., Vol. 195, No. 1, pp.173-183.

Mertz, W. (1982) 'Clinical and public health significance of chromium', in Prasad, A.S. (Ed.): Clinical, Biochemical and Nutritional Aspects of Trace Elements, pp.315-323, Alan R. Liss, Inc., New York.

O’Dell, B.L. and Sunde, R.A. (Eds.) (1997) Handbook of Nutritionally Essential Mineral Elements, Marcell Dekker Inc., New York.

Parchure, S.N. (1983) Charak Samhita, Sagar Publications, Pune, India.

Patel, N.G. (1986) 'India's traditional medicine: Ayurveda', in Steiner, R.P. (Ed.): Folk Medicine: the Art and the Science, pp.41-45, American Chemical Society, Washington, DC.

Powel, J.J., Burden, T.J. and Thompson, R.P.H. (1998) 'In vitro mineral availability from digested tea: a rich dietary source of manganese', Analyst, Vol. 123, No. 8, pp.1721-1724.

Prasad, A.S. (1993) Essential and Toxic Elements in Human Health and Disease: An Update, Wiley-Liss, New York.

Prasad, A.S. (Ed.) (1982) 'Clinical and biochemical spectrum of zinc deficiency in human subjects', Clinical, Biochemical and Nutritional Aspects of Trace Elements, pp.3-6, Alan R. Liss, Inc., New York.

Rajurkar, N.S. and Pardeshi, B.M. (1997) 'Analysis of some herbal plants from India used in the control of diabetes mellitus by NAA and AAS techniques', Appl. Radiat. Isot., Vol. 48, No. 8 , pp.1059-1062.

Reddy, M.B., Chidambaram, M.V. and Bates, G.W. (1987) 'Iron bio-availability', in Winkelmann, G., van der Helm, D. and Neilands, J.B. (Eds.): Iron Transport in Microbes, Plants and Animals, pp.429-443, VCH, New York.

Sharma, P.V. (1993) Dravya Guna Vigyan, Varanasi, Chaukhamba Bharati Academy, India.

Shils, M.E. and Young, V.R. (1988) Modern Nutrition in Health and Diseases, 7th ed., K.M. Verghese Co., India.

Sigel, H. (Ed.) (1978) 'Iron in model and natural compounds', in Metals in Biological Systems, Vol. 7, pp.417-425, Marcel Dekker, New York.

Thunus, L. and Lejeune, R. (1994) 'Cobalt, zinc', in Seiler, H.G., Sigel, A. and Sigel, H. (Eds.): Handbook on Metals in Clinical and Analytical Chemistry, p.333, p.667, Marcel Dekker, New York.

Underwood, E.J. (1977) Trace Elements in Human and Animal Nutrition, Academic Press, New York.

Zetic, V.G., Tomas, V.S., Grba, S., Lutilsky, L. and Kozlek, D. (2001) 'Chromium uptake by saccharomyces cerevisiae and isolation of glucose tolerance factor from yeast biomass', J. Biosci., Vol. 26, No. 2, pp.217-223.

\section{Bibliography}

Razic, S., Onjia, A. and Potkonjak, B. (2003) 'Trace elements analysis of Echinacea Purpurea - herbal medicinal', J. Pharm. Biomed. Anal., Vol. 33, No. 4, pp.845-850. 